\title{
Technology acceptance and usage behaviour of content and language integrated learning teachers in Turkey
}

Özge Koç a,1,* Gülru Yüksel b,2, Emin Altunc,3

a Velibaba Anatolian High School, Sapanbağları Mahallesi, Yenipazar Caddesi, No:31 Daire:3 Pendik-İstanbul, 34893, Turkey

${ }^{\mathrm{b}}$ Faculty of Education, Yıldız Teknik Universitesi, Davutpasa Kampusu, Egitim Fakultesi, İngilizce Ogretmenligi Bolumu, Esenler-Istanbul, 34180 , Turkey

'Ca' Foscari University of Venice, Ramo della Palada, 392/A Giudecca, Venice, 30133, ITALY

${ }^{1}$ ozgekoc824@gmail.com*; ${ }^{2}$ gulruyuksel2002@gmail.com; ${ }^{3}$ alltunemin@gmail.com

* corresponding author

\section{ARTICLE INFO}

Article history

Received 18 June 2021

Revised 3 August 2021

Accepted 20 August 2021

Keywords

Content and Language Integrated Learning (CLIL)

Information and Communication

Technologies (ICT)

Technology Acceptance Model (TAM)

\section{ABSTRACT}

Content and language integrated learning (CLIL) is an approach that combines content and language objectives. Despite substantial expansion over the past two decades, its successful adoption raises several challenges for teachers. Teachers turn to information and communication technologies (ICT) to solve their problems. This study aims to investigate technology acceptance and use of English language teachers adopting the CLIL approach in Turkey, and to identify the difficulties they encounter while integrating technology into practice. The study is explanatory in research design and employs the Technology Acceptance Model (TAM) developed by Davis (1989) as a framework. A 27-item Likert-type questionnaire was used to gather data from 61 teachers practicing in private and public schools. The results showed a statistically significant difference in technology integration intention and use behaviors of teachers. The qualitative data suggested that among the difficulties faced by CLIL teachers were facilitating environments, managerial assistance, and teacher technology awareness.

This is an open access article under the CC-BY-SA license.

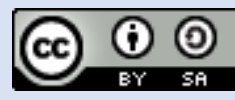

How to Cite: Koç, Ö., Yüksel, G., \& Altun, E. (2021). Technology acceptance and usage behaviour of content and language integrated learning teachers in Turkey. English Language Teaching Educational Journal, 4(2), $113-124$

\section{Introduction}

Content and Language Integrated Learning (CLIL) is an approach that combines content and language objectives. It is defined as "a type of instruction where non-language subject (content) is mediated to the learnera through a foreign language as a means of communication" (Coyle et al. 2010, p. 31). Though teaching content through a second/foreign language is not a new concept, interest in adopting CLIL methodology has gained momentum in European countries over the last two decades (Eurydice, 2012). Since its emergence, CLIL has fundamentally changed language teaching and learning and has become an inherent element of education at all levels in different countries across Europe (Eurydice, 2012).

CLIL was first introduced in Turkey in the 1950s in the Maarif Schools, later renamed Anatolian High Schools (Çetintaş \& Genç, 2001). The main aim of establishing such schools was to keep up with rapid economic and technical developments by increasing the number of young people who were fluent in world languages and could benefit from scientific studies. (TBMM Tutanak Dergisi, 1955 as cited in Çetintaş \& Genç, 2001). The medium of instruction in these schools was a foreign language, particularly English. By the late 1990s, some private schools have begun to introduce CLIL at the 
primary and secondary levels. An increase in the number of schools implementing CLIL has been noted, especially over the last two decades. It has recently been implemented in several Social Science High Schools, as well as private elementary and secondary schools in a number of cities (Tanış \& Dikilitaş, 2019).

A review of the literature reveals that despite the attention it receives and the attempts undertaken to incorporate this approach into classroom practices, the implementation is not without difficulties. Various difficulties have been identified in the studies conducted in different context. Most CLIL teachers turn to Information and Communication Technologies (ICT) to overcome the difficulties they encounter. However, ICT integration and its potential impact on teaching and learning in CLIL classrooms need to be explored from a variety of angles. The Technology Acceptance Model (Davis, 1989) posits that actual usage of technology is motivated by an individual's attitude. In other words, the degree of acceptance of technology predicts the individual's actual use (Ajibade, 2018). Since teachers are one of the major actors in any effective integration of technology into education (Teo, 2011), investigating their technology use intention and behavior is crucial. However, previous studies in the field have mostly concentrated on how technology and web 2.0 tools can be used to deliver content and facilitate language skills in CLIL classrooms, and the impact of technology usage on students' motivation and engagement in the learning process (e.g., O'Dowd, 2018; Mede \& Çınar, 2019; Zhao \& Lei, 2019). Research exploring teachers' technology acceptance and their actual technology use behaviour in CLIL settings is scarce in number. The purpose of this study is to contribute to the literature by investigating the technology acceptance and use of Turkish EFL teachers who implement CLIL approach in their classrooms.

\subsection{ICT Use in CLIL Classrooms}

Various studies investigating CLIL practices in different educational settings revealed that during implementation, teachers experience a variety of challenges. Some of the problems identified in the studies conducted in the European context include insufficient teacher training programs and institutional support for professional growth (Banegas, 2012; Denman, Tanner \& de Graaff, 2013); low language proficiency levels of students that lead to comprehension problems and unsatisfactory development of students' productive skills (Pladevall-Ballester, 2015); teachers' inadequate expertise in non-linguistic subject-areas (Smajla, 2021); classroom management issues experienced during instruction; the amount of time required for lesson planning and class preparation (Pladevall-Ballester, 2015); and insufficient teaching materials (Roiha, 2014). In a recent cross-cultural study, exploring the perceptions of managers and teachers about CLIL in Spain, Italy, and Turkey, Korbek (2019) found that support for teacher training, material design and use, and collaboration among teachers within their full schedule are the challenges prevalent in all three contexts.

Similar difficulties have been reported in the Turkish context. Teachers' and students' perceptions of science teaching and learning were investigated by Erdem and Morgil (1992), who found that low language proficiency and incomplete content knowledge of students, insufficient teaching resources, and inadequate expertise in teaching language subject-areas are the major difficulties expressed by the teachers. In another study examining the opinions of teachers and students on education in a foreign language at Anatolian High Schools, Mirici et al. (2000) reported that the majority of teachers have unfavorable perceptions and they consider students' difficulty in understanding the content as a fundamental problem. However, in a recent study Tanış and Dikilitaş (2019) reported that teachers practicing in a private school hold positive perceptions about CLIL instruction. Despite positive perceptions, they also expressed various problems, including learners' low levels of English proficiency, inadequate training support, and lack of sufficient instructional materials.

\subsection{Technology Acceptance Model (TAM)}

Today, CLIL teachers utilize information and communication technologies (ICT) to tackle the challenges they confront. Previous research on the effect of technology integration in education has suggested that it promotes innovative instructional methods while also improves the quality of education (McKnight et al., 2016). Effective technology integration is a complicated process that necessitates careful consideration of a variety of factors, such as curriculum alignment, students needs and abilities, and teachers' beliefs (OECD, 2015; Siddiq, Scherer \& Tondeur, 2016). Among these factors, teachers' beliefs play a significant role (Borg, 2015), because teachers shape their classroom practices per their subjective judgments about the teaching situation (Tondeur, et al., 2017). Findings from past research indicated that the acceptance and use of technology is troublesome for teachers 
(Berrett, Murphy \& Sullivan, 2012). In this regard, researchers have proposed and adopted various models as a framework for understanding the technology use, beliefs, and behaviors of the teachers. The Technology Acceptance Model (TAM) developed by Davis (1989) is one of the widely used models. The model conceptualizes that individual's actual use is determined by four variables of behavioral intentions and external variables (Scherer et al., 2019). Figure 1 illustrates the model as developed by Davis (1989).

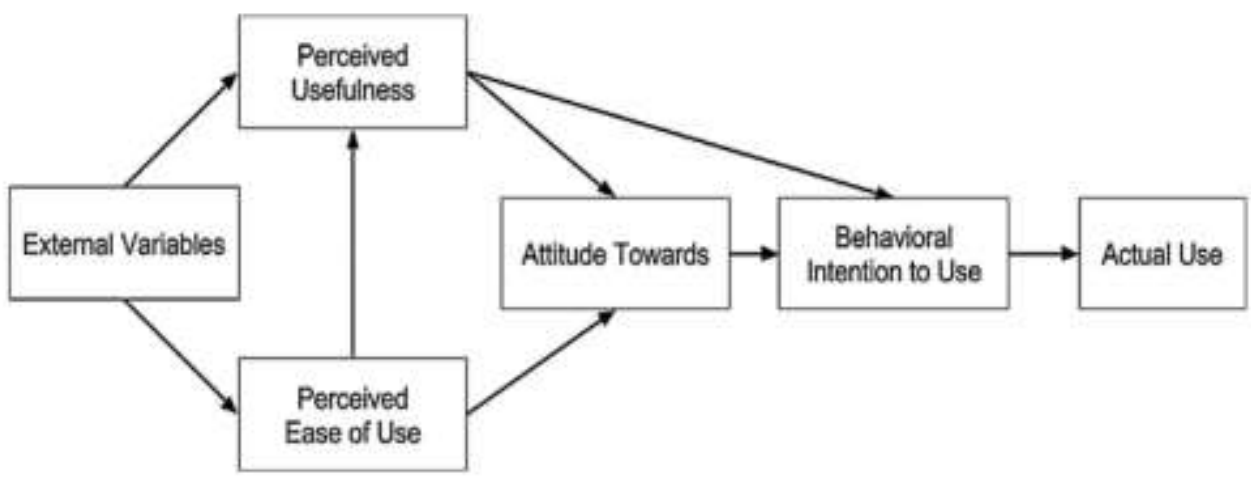

Figure 1: Technology Acceptance Model (TAM) (based on, Davis, 1989)

As Figure 1 illustrates, perceived usefulness (PU) and perceived ease of use (PEU) are the key variables that directly or indirectly explain the outcome (Marangunić \& Granić, 2015). According to Davis (1989), perceived usefulness is "the degree to which an individual believes that using a particular system would enhance his or her job performance," while perceived ease of use is "the degree to which a person believes that using a particular system would be free of effort" (p. 320). Previous studies into the relationship between these variables found that an individual's perception of ease of use directly impacts his or her perception of usefulness (Hew et al., 2019), which in turn greatly influences his or her attitudes toward use (Teo, Huang \& Hoi, 2018). Attitude toward use further influences an individual's behavioral intention to use technology (Teo, Huang \& Hoi, 2018).

The relation between intention and actual use behavior is a crucial aspect of technology-use behavior (Wu \& Du, 2012). Findings from past studies suggested that teachers use technology either for teacher-centered or for student-centered reasons (Muganga \& Ssenkusu, 2019). While the former use aims to deliver language-related information and consolidate skills in isolation (e.g., vocabulary, grammar, listening), the latter use aims to improve students' higher-order thinking skills (Jeffrey \& Clark, 2019). In this vein, a recent study by Liu, Wang and Koehler (2019) adopted the TAM model to explore the strength and underlying mechanisms of the intention-use link with 198 foreign language teachers in China. The findings revealed a discrepancy in intention-behavior due to Chinese foreign language teachers' use of student-centered technology. In the same study, Liu et al. (2019) also investigated the factors influencing the Chinese EFL teachers' technology use and found that conditions facilitating technology use (i.e., hardware and software resources in hand) and teachers' technological knowledge are the most significant factors influencing teachers' technology use. Teachers' technological knowledge and facilitating conditions are found as the main predictors of teachers' intentions to adopt Web 2.0 technologies (Mei et al., 2017). These are also reported to be the variables affecting teachers' views and attitudes (Teo, Huang \& Hoi, 2018).

Furthermore, some researchers tested the impact of several demographic variables on teachers' technology acceptance, including gender, age, and years of teaching experience. However, the results remained inconclusive. For example, in an earlier study with 248 Iranian EFL teachers, Rahimi and Yadollahi (2011) found that ICT usage negatively correlates with teachers' age and years of experience. In another study, Mahdi and Al-Dera (2013) investigated the effect of gender, age, years of teaching on EFL teachers' technology integration with 46 in-service EFL teachers in Saudi Arabia. The findings revealed that while age and experience do not have a significant effect, gender significantly influences technology integration. In the study, males are found to use ICT more frequently than females. 
The literature reviewed clearly indicates that research into technology integration in CLIL classrooms is still in its infancy. To the best of the researchers' knowledge, there is not any study investigating EFL teachers' intention and actual use of technology for teacher-centered or studentcentered purposes during CLIL practices in Turkey. This study was motivated by these research questions:

1. Is there an intention-behavior discrepancy in teacher-centered and student-centered technology use among CLIL teachers in Turkey?

2. Does CLIL teachers' intention to use information technologies vary according to different independent variables (gender, teaching experience, training, school type and level)?

3. What are the challenges that CLIL teachers experience in technology integration?

\section{Method}

The study is explanatory in research design which attempted to investigate the technology use beliefs and behaviors of CLIL teachers. To answer the first two research questions quantitative data were collected via an online questionnaire. For the third research question qualitative data were collected through an open-ended question.

\subsection{Context}

This study was carried out with CLIL teachers practicing in both private and state schools. In Turkey, education is governed by a central system, with the Ministry of National Education (MoNE) regulating all schools (both state and private). The MoNE is in charge of determining and implementing all policies in primary and secondary education. The ministry is the only decisionmaking authority in curriculum development, textbook approval and the assessment procedures. Although schools have little autonomy in determining curriculum and assessment policies, the regulations give teachers a lot of leeway in defining the content and delineating the teaching and learning practices.

The MoNE likewise monitors the quality of education and teacher qualifications. All prospective English language teachers must be competent in planning lessons, arranging interactive learning environments appropriate for English language learners, and utilizing materials, technological resources/tools, methods, and strategies suitable for the English teaching process. They should also be able to monitor and assess students' language learning process and provide adequate guidance, as well as keep up with professional advances in the area (Republic of Turkey Ministry of Education, 2016).

\subsection{Participants}

Snowball sampling method was used in the study. Potential participants were contacted via personal e-mails and requested to share the link of an online survey with colleagues who adopt CLIL in their classrooms. A total of 61 CLIL teachers volunteered to participate in the study (35 Female, 26 Male). At the time of data collection, 36 out of the 61 teachers were practicing in private schools, while 25 were practicing in state schools. The majority of the participants (75\%) had more than five years of experience in teaching English. The participants' teaching experience range was $0 \sim 5$ years (25\%), 6 10 years (37.5\%), 11 15 years (23.2\%), 16 20 years (10.7\%) and over 21 years (3.6\%). Both state and private school teachers had almost comparable experience in adopting CLIL approach $(\mathrm{M}=3.5$ and $\mathrm{M}=3.6$, respectively). Table 1 presents detailed information on the study cohort.

Table 1. Study Cohort

\begin{tabular}{ccccc}
\hline School Type & Level & N & $\begin{array}{c}\text { Mean Y. of CLIL } \\
\text { Experience }\end{array}$ & $\begin{array}{c}\text { Participants with ICT } \\
\text { Training (N) }\end{array}$ \\
\hline \multirow{2}{*}{ State } & Primary & $9(6 \mathrm{~F} / 3 \mathrm{M})$ & 2.8 & 4 \\
& Secondary & $16(8 \mathrm{~F} / 8 \mathrm{M})$ & 3.7 & 5 \\
\multirow{3}{*}{ Private } & Primary & $21(17 \mathrm{~F} / 4 \mathrm{M})$ & 2.7 & 17 \\
& Secondary & $15(4 \mathrm{~F} / 11 \mathrm{M})$ & 4.6 & 11 \\
\hline
\end{tabular}




\subsection{Data Collection Tool}

Data were collected by using an adapted version of a questionnaire developed by Liu et al. (2019). The questionnaire had three sections consisting of 28 items. The first section (6 items) sought to elicit participants' demographic information including gender, range of teaching experience, school type and level, years of experience in practicing CLIL, and training received to integrate technology into the classroom. The second section included nine items that asked the respondents to express their perceptions on the following three factors in TAM: Perceived Usefulness (PU) (3 items), Perceived Ease of Use (PEU) (3 items), and Technology-use Intention (INT) (3 items). The last section consisted of nine items that asked the participants to rate their Teacher-centered Technology Use (TTU) (4 items) and Student-centered Technology Use (STU) (5 items) on a 5-point scale. The items in the second and third sections were modified to fit the objectives of the study by adding "CLIL" to the statements where applicable. Furthermore, an open-ended question was added to gather information about the challenges that CLIL teachers experienced while integrating technology into their classrooms.

Cronbach's alpha reliability for these five constructs was reported to range from 0.73 to 0.85 (Liu et al., 2010). In the current study, the reliability of the questionnaire was checked using Cronbach's coefficient $\alpha$ and was found to be 0.80 for the whole scale.

\subsection{Data Collection Procedure}

The questionnaire was turned into an online survey and distributed as email links. The participants completed the questionnaire anonymously. In the initial part of the online survey the participants were informed about the aim of the study and requested to waive informed consent by clicking on a button.

\subsection{Data Analysis}

The following statistical procedures were used for data analysis: For normality analysis of continuous variables, descriptive statistics and histograms were used. Both visual and statistical inspection as assessed by P-P plots and Kolmogorov-Smirnov (K-S) tests indicated a non-normal distribution. Therefore, the researchers utilized Friedman's two-way ANOVA test to detect differences. Mann-Whitney $U$ and Kruskal Wallis $\mathrm{H}$ tests were used for group comparisons. The level of significance was taken as .05 in all statistical procedures.

The responses given to the open-ended questions were analyzed using open-coding analysis (Bogdan \& Biklen, 2012; Strauss \& Corbin, 2015). During the analysis, the researchers independently read the responses, marked and coded each meaningful unit. Following the initial coding, codes were grouped into categories and themes. Later, the researchers cross-checked the codes, and discrepancies in coding and/or categorizations were resolved upon discussion. The reliability of the analysis was achieved by this cross-checking process (Cohen, Manion, \& Morrison, 2017). The inter-rater reliability was found to be $90 \%$.

\section{Findings and Discussion}

\subsection{Quantitative Findings}

The first research question investigated whether there was an intention-behavior discrepancy in teacher-centered and student-centered technology use among CLIL teachers. When descriptive statistics were examined, CLIL teachers had positive perceptions about the usefulness of technology and intention to use ( $M=4.45$, and $M=4.55$, respectively). However, their perception about the ease of use of technology in CLIL classrooms was comparatively lower $(M=3.10)$. A high level of actual use was also demonstrated by the mean values of teacher-centered and student-centered technology domains ( $M=4.17$ and $M=4.47$, respectively). The high mean value of the actual use suggested that Turkish CLIL teachers actively utilized technology not only to support student learning, but also for teacher-centered purposes. However, Friedman's Two-Way ANOVA indicated a statistically significant difference in intention-behavior in technology integration $\left(\chi^{2}(4)=86.741, \mathrm{p}=0.000\right)$. DunnBonferroni post hoc tests revealed a statistically significant difference between the technology use intention and student-centered technology use $(Z=-4.865, \mathrm{p}=0.007)$. There was no significant difference between technology use intention and teacher-centered technology use $(\mathrm{p}=0.007)$. This finding suggests that there was a gap between CLIL teachers' intention and technology use behavior. 
This finding echoes the recent study by Liu et al. (2019). Similar to the finding, Liu et al. (2019) found an intention-behavior gap for Chinese foreign language teachers in the use of student-centered technology.

A series of non-parametric tests were run to examine whether CLIL teachers' intention to use information technologies differed according to independent variables under investigation: gender, teaching experience, training, school type, and level. Mann-Whitney $\mathrm{U}$ tests revealed statistically significant gender difference in perceived ease of use $(\mathrm{U}=273.5, Z=-2.669, \mathrm{p}=0.008)$ and teachercentered technology use $(\mathrm{U}=293.5, Z=-2.422, \mathrm{p}=0.015)$ in favor of females. In other words, female CLIL teachers' levels of perceived ease of use and actual use of technology for teacher-centered purposes were higher than that of male teachers. No significant differences were detected with respect to other variables $(p \geq 0.05)$. Other studies have also shown significant gender differences; however, cultural variation should be noted here. Males were found to use ICT more frequently than females in the study by Mahdi and Al-Dera (2013), yet females' actual use was higher in this study.

\subsection{Qualitative Findings}

Regarding the challenges that CLIL teachers experienced while integrating technology into their classrooms, the responses given to the open-ended question were analyzed. The analysis yielded four main challenge categories: facilitating condition, teachers' knowledge, students' ability, and managerial and policy issues. The categories and themes emerged from the participants' responses, as well as frequencies and percentages by school type are given in Table 2.

Table 2. Challenges Experienced by CLIL Teachers

\begin{tabular}{|c|c|c|c|c|c|c|c|}
\hline \multirow{2}{*}{ Category } & \multirow{2}{*}{ Theme } & \multicolumn{2}{|c|}{ Total } & \multicolumn{2}{|c|}{ Private } & \multicolumn{2}{|c|}{ State } \\
\hline & & $\mathbf{n}$ & $\%$ & $\mathbf{n}$ & $\%$ & $\mathbf{n}$ & $\%$ \\
\hline \multirow{6}{*}{$\begin{array}{l}\text { Facilitating } \\
\text { condition }\end{array}$} & Material shortage & 17 & 27.4 & 9 & 14.8 & 8 & 14.0 \\
\hline & Hardware shortage & 9 & 14.5 & 4 & 6.6 & 5 & 8.8 \\
\hline & Software shortage & 3 & 4.8 & 1 & 1.6 & 2 & 3.5 \\
\hline & Time limitation & 25 & 40.3 & 19 & 31.1 & 6 & 10.5 \\
\hline & Training & 8 & 12.9 & 2 & 3.3 & 6 & 10.5 \\
\hline & Sub-total & 62 & 52.5 & 35 & 57.4 & 27 & 47.4 \\
\hline \multirow[t]{4}{*}{ Teacher knowledge } & $\mathrm{TK}^{*}$ & 7 & 30.4 & 3 & 4.9 & 4 & 7.0 \\
\hline & TCK & 5 & 21.7 & 1 & 1.6 & 4 & 7.0 \\
\hline & TPK & 11 & 47.8 & 10 & 16.4 & 1 & 1.8 \\
\hline & Sub-total & 23 & 19.5 & 14 & 23.0 & 9 & 15.8 \\
\hline \multirow[t]{4}{*}{ Student abilities } & Device use & 1 & 12.5 & 1 & 1.6 & 0 & 0.0 \\
\hline & Search skills & 5 & 62.5 & 4 & 6.6 & 1 & 1.8 \\
\hline & Background knowledge & 2 & 25 & 0 & 0.0 & 2 & 3.5 \\
\hline & Sub-total & 8 & 6.8 & 5 & 8.2 & 3 & 5.3 \\
\hline \multirow{4}{*}{$\begin{array}{l}\text { Managerial/ Policy } \\
\text { issues }\end{array}$} & School policy & 11 & 44 & 7 & 11.5 & 4 & 7.0 \\
\hline & Curricular restrictions & 7 & 28 & 0 & 0.0 & 7 & 12.3 \\
\hline & Peer support \& feedback & 7 & 28 & 0 & 0.0 & 7 & 12.3 \\
\hline & Sub-total & 25 & 23.7 & 7 & 11.5 & 18 & 31.6 \\
\hline \multicolumn{2}{|c|}{ GRAND TOTAL ${ }^{* *}$} & \multicolumn{2}{|c|}{118} & \multicolumn{2}{|c|}{61} & \multicolumn{2}{|c|}{57} \\
\hline
\end{tabular}

In the facilitating condition category, five main themes emerged from the responses, namely material, hardware and software shortage, time limitation, and training. Despite the fact that this was the most frequently reported challenge category by the participants $(52.5 \%)$, there were worth noting 
differences in the distribution of themes by school type. Time limitation (31.1\%) and material shortage (14\%) were reported as basic problems experienced by private school teachers. For example, a private school teacher stated that "There are not enough materials to present the content. As teachers, we need to find the materials, edit the videos to align our students' level, and to design activities using technology. So, it takes a lot of time, and we do not have enough time". Similar to private school teachers, state school teachers expressed material shortage (14\%) and time limitation (10.5\%) as basic difficulties they confronted. A teacher acknowledged the scarcity of materials and their lack of time by saying, "We do not have enough materials. It is hard to find, adopt and develop materials related to the content. This takes a lot of time and effort".

CLIL teachers practicing at state schools mentioned hardware and software shortages more frequently than private school teachers. One of the state school teachers mentioned using his own equipment to overcome the shortage and explained that hardware shortage was a major problem, and added, "Our school does not have any technological infrastructure, including smart boards, computers, and projectors. So, we use our personal tools and equipment in the classroom". This indicated that state schools needed urgent support. Although private schools invested money in hardware and software, teachers could still experience difficulties. A private school teacher expressed that "Sometimes there are some obstacles in my classroom related to the smart board. It's not working properly". Consistent with the findings, Pladevall-Ballester (2015) and Roiha (2014) previously reported that insufficiency of materials and inadequate time for course design as problems encountered by CLIL teachers.

Technology integration into foreign language classrooms is a demanding task, and teachers need support and training. The findings revealed that a need for training was more pronounced in state schools (10.5\%) than in private schools (3.3\%). A state school teacher explained this need by saying, "I do not receive any training about how to use technology in language classrooms effectively except for seminars I attended voluntarily. I need more detailed and structured training". Unlike state schools, private schools supported professional development either via in-house training events or by allowing teachers to attend various teacher training seminars. Still, a few private school teachers mentioned that they did not receive any training. For example, an experienced teacher remarked, "I do not receive any training to integrate technology, so day-by-day, I am learning to use it in the classroom and it takes time $[\ldots] "$.

Knowledge was the second category of challenges for private school teachers (23\%), but it was the third category for state school teachers $(15.8 \%)$. In this category, the most frequently observed challenge experienced by private school teachers was the technological pedagogical knowledge (16.4\%). A comment by a novice private school teacher said, "They [the students] sometimes can be distracted while they are watching long videos" clearly suggests that teachers lacked knowledge in possible limitations of the technologies they use and that they needed guidance and training in pedagogical design strategies. The responses of the state school teachers, on the other hand, indicated that they experienced problems due to insufficient technological knowledge (7\%) and technological content knowledge (7\%). These issues were explicitly mentioned in the following statements by two qualified teachers:

\section{"Learning technology takes time for teachers. Students know how to use smart boards better than me." \\ "I am still trying to learn by myself, that's why it is so hard [...] I do not know websites that provide resources for CLIL."}

The emergence of knowledge as the second most commonly cited challenge was consistent with the low mean score calculated for perceptions of ease of technology use. This challenge might also explain the significant difference found between technology use intention and student-centered technology use. The findings that teachers needed training in technology integration, and that institutional support for professional growth was lacking comply with previous studies by Banegas (2012), Denman, Tanner and de Graaff (2013) and Korbek (2019). Teachers' technological knowledge and facilitating conditions have been identified as variables affecting teachers' opinions per technology use (Mei et al., 2017; Teo, Huang \& Hoi, 2018).

Student related difficulties (i.e., students' ability to use technological devices and background knowledge - both linguistic and content) were the least frequently mentioned challenges experienced 
by both groups of teachers (6.8\%). While private school teachers expressed students' ineffective internet search skills as a problem (6.6\%), state school teachers were mostly concerned about their students' language level and background of content knowledge (3.5\%). One private school teacher explained the difficulty by saying, "Students have difficulty in using technology and doing research. School does not allow students to use technology at school, so we cannot be a model for them and foster how to use technology". On the contrary, a state school teacher raised her concerns by saying,

\section{"[...] students' language level for some of the contents is a problem, they do not have enough background knowledge [..]".}

Catalonian teachers in Pladevall-Ballester's (2015) study mentioned comparable student related difficulties shared by private and state school teachers who participated in the study.

CLIL teachers spoke of the managerial and policy issues as notable challenges they encountered. While school policies restricting the use of technological tools appeared to be a problem shared by both groups of teachers, teachers practicing in state schools raised two other issues. The issues most commonly expressed by the state school teachers were the curricular limitations (12.3\%), and lack of peer support and feedback (12.3\%). One state school teacher said:

\section{"[...] lesson hours are not enough, the curriculum has deficiencies in terms of CLIL implementation"}

and another teacher complaint about missing support and collaboration among colleagues by saying:

\section{"[...] other teachers have negative attitudes towards my endeavors; I could not get feedback from my peers".}

These expressions indicated that state school teachers felt a need to share their classroom experiences with their colleagues. Unlike private school teachers, teachers in state schools had more flexibility in choosing the method they would adopt. Thus, there was no standard teaching method practiced by all teachers from the same school. Unlike state schools, the case was quite the opposite in private schools. They were required to work collaboratively and followed precisely the same procedures. This was highlighted by one of the teachers:

"School policy is a major problem. The administration does not allow us to go online for some websites; I would like to trigger students' creativity with technology but we are not free to choose and use our own activities".

Indeed, similar to the study, Korbek (2019) observed a lack of collaboration among teachers in Italian, Spanish and Turkish contexts. The differences the researchers observed between private and state school teachers with respect to problems encountered suggested that school setting may have impact on teachers' technology usage in CLIL classes. The implementation of CLIL approach requires teamwork rather than individual efforts. It may be concluded that from both the quantitative and qualitative data, they showed that the gap between intention to use and actual use resulted from a combination of these challenges.

\section{Conclusion}

Three main conclusions can be drawn from the results presented above. To begin with, the findings showed that actual use behaviors can be taken as factors influencing the technology integration intentions of the CLIL teachers. Teacher-centered purposes, as quantitative findings suggested, play a crucial role. Instead of student-centered purposes or student's active participation most teachers use technology to improve their work performance in the classroom, to enhance their effectiveness, and to accomplish the teaching-learning processes easily and quickly. Furthermore, negative externalities could have an effect on teachers' actual use of technology in the classroom. The quantitative results of the study, corroborating the findings of Liu et al. (2019), showed that there is a discrepancy between Turkish CLIL teachers' technology integration intention and their actual use.

Gender wise disparities in the use of technology in the classroom is another point worth to mention. Whereas many male teachers enabled their students to engage with technology in order to complete language learning tasks, female teachers used technology for more teacher-centered activities. CLIL teachers' responses suggested that this tendency is closely linked to institutional context, lack of knowledge and experience in student-centered teaching, and assessment pressure. Apart from these 
factors, previous experiences of teachers might also be influencing their classroom practices. As Hubbard (2018) mentioned "currently practicing teachers do not experience the integration of technology as students in their language classes as students" (p. 1). Teachers must gain both knowledge and skills about how to incorporate new technologies in a student-centered manner.

Finally, facilitating conditions seem to be the most prevalent problem among the challenges that CLIL teachers experience when implementing the approach. Due to time constraints and material shortages, both private and state school teachers presented the content without providing practice and consolidation opportunities for the retention of the content. While teachers in public schools were adversely affected by the shortage of technological resources, private school teachers still encountered difficulties in utilizing the resources despite having the necessary equipment. This limited teachers' ability to present the subject in depth and design activities that would appeal to students' cognitive and affective domains. When state and private school teachers were compared with respect to their needs in selecting and using technological resources, teachers in private schools seemed to be more competent. Most state school teachers needed support and in-service training. Teachers expressed that finding educational websites and applications that provide content knowledge was a real challenge, and that they also needed guidance in how to adapt the resources they found.

One major implication of our findings is that there is a discrepancy between CLIL teachers' technology use intentions and their actual use. They mainly utilize technology for teacher-centered purposes. This clearly shows that CLIL teachers not only need in-service training in technological knowledge, but also in technological pedagogical and technological content knowledge. Teacher competencies in these areas can be strengthened through webinars as well as workshops that can give teachers hands-on experience. Furthermore, school management strategies that discourage teachers from exploring innovative technologies, approaches and techniques should be reconsidered.

Given the exploratory nature of the study and the relatively small sample size, the findings cannot be generalized across other contexts. Further work on CLIL teachers' actual technology use and classroom practices is needed. In the current study data were collected using a questionnaire, though. Future studies may include observational data to have a more comprehensive picture of how teachers utilize technology in student-centered practices during instruction.

\section{Declarations}

Author contribution: The first author initiated the research ideas, was in charge of resources, investigation, data collection and writing and editing; the second author was in charge of conceptualization, supervision, data analysis and presentation, and editing; the third author was in charge of investigation, data collection, reviewing.

Funding statement: The research did not receive any funding.

Conflict of interest: The authors declare no conflict of interest.

Additional information: No additional information is available for this paper.

\section{REFERENCES}

Ajibade, P. (2018). Technology acceptance model limitations and criticisms: Exploring the practical applications and use in technology-related studies, mixed-method, and qualitative researches. Library Philosophy and Practice, 1-13. Retrieved from https://core.ac.uk/download/pdf/189486068.pdf

Banegas, D. L. (2012). CLIL teacher development: Challenges and experiences. Latin American Journal of Content \& Language Integrated Learning, 5(1), 46-56. https://doi.org/10.5294/lacli1.2012.5.1.4

Berrett, B., Murphy, J., \& Sullivan, J. (2012). Administrator insights and reflections: Technology integration in schools. Qualitative Report, 17(1), 200-221. Retrieved from http://www.nova.edu/ssss/QR/QR171/berrett.pdf

Bogdan, R. C., \& Biklen, S. K. (2012). Qualitative research for education: An introduction to theory and methods. Boston: Pearson Education. 
Borg, S. (2015). Teacher cognition and language education: Research and practice. New York: Bloomsbury Publishing.

Cohen, L., Manion, L., \& Morrison, K. (2017). Research methods in education ( $8^{\text {th }}$ ed.). London: Routledge.

Coyle, D., Hood, P., \& Marsh, D. (2010). Content and Language Integrated Learning. Stuttgart: Ernst Klett Sprachen.

Çetintaş, B., \& Genç, A. (2001). Foreign language teaching at Anatolian schools following the education reform. Hacettepe Universitesi Egitim Fakultesi Dergisi, 20, 51-56.

Davis, F. D. (1989). Perceived usefulness, perceived ease of use, and user acceptance of information technology. MIS Quarterly, 13(3), 319-340.

Denman, J., Tanner, R., \& de Graaff, R. (2013). CLIL in junior vocational secondary education: Challenges and opportunities for teaching and learning. International Journal of Bilingual Education and Bilingualism, 16(3), 285-300. https://doi.org/10.1080/13670050.2013.777386

Erdem, E., \& Morgil, İ. (1992). Türkiye'de yabancı dilde öğretim yapan orta öğretim kurumlarında fen öğretimi ve sorunlar1 [Science teaching in secondary schools in Turkey that offer foreign language education and the challenges], Hacettepe Üniversitesi Eğitim Fakültesi Dergisi, 7, 251-260.

Eurydice. (2012). Key data on education in Europe 2012. Retrieved from: https://ec.europa.eu/eurostat/documents/3217494/5741409/978-92-9201-242-7-EN.PDF/d0dcb0da5c52-4b33-becb-027f05e1651f

Hew, K. F., Lan, M., Tang, Y., Jia, C., \& Lo, C. K. (2019). Where is the "theory" within the field of educational technology research? British Journal of Educational Technology, 50(3), 956-971. https://doi.org/10.1111/bjet.12770

Hubbard, P. (2018). Technology and professional development. In J. I. Liontas, M. DelliCarpini \& G. Kessler (Eds.), The TESOL Encyclopedia of English Language Teaching (pp. 1-6). Hoboken: John Wiley \& Sons, Inc.

Jeffrey, D. M., \& Clark, R. M. (2019). Supplementing Western perspectives of learner-centered instruction with a Daoist approach towards authentic power sharing in the classroom. International Journal of Contemporary Education, 2(1), 9-16. https://doi.org/10.11114/ijce.v2i1.4016

Korbek, G. (2019). Teaching perspectives on CLIL in different educational contexts. Università Degli Studi Di Palermo, Italy. Retrieved from https://iris.unipa.it/handle/10447/395496\#.YR4CbY4zaUl

Liu, I. F., Chen, M. C., Sun, Y. S., Wible, D., \& Kuo, C. H. (2010). Extending the TAM model to explore the factors that affect Intention to Use an Online Learning Community. Computers \& education, 54(2), 600-610.

Liu, H., Wang, L., \& Koehler, M. J. (2019). Exploring the intention-behavior gap in the technology acceptance model: A mixed-methods study in the context of foreign-language teaching in China. British Journal of Educational Technology, 50(5), 2536-2556. https://doi.org/10.1111/bjet.12824

Mahdi, H. S., \& Al-Dera, A. S. A. (2013). The impact of teachers' age, gender and experience on the use of information and communication technology in EFL teaching. English Language Teaching, 6(6), 57-67. http://dx.doi.org/10.5539/elt.v6n6p57

Marangunić, N., \& Granić, A. (2015). Technology Acceptance Model: A literature review from 1986 to 2013. Universal Access in the Information Society, 14(1), 81-95. https://doi.org/10.1007/s10209-014-0348-1

McKnight, K., O'Malley, K., Ruzic, R., Horsley, M. K., Franey, J. J., \& Bassett, K. (2016). Teaching in a digital age: How educators use technology to improve student learning. Journal of Research on Technology in Education, 48(3), 194-211. https://doi.org/10.1080/15391523.2016.1175856 
Mede, E., \& Çınar, S. (2019). Implementation of Content and Language Integrated Learning and its effects on student motivation. Latin American Journal of Content \& Language Integrated Learning, 11(2), 216235. https://doi.org/10.5294/lacli1.2018.11.2.3

Mei, B., Brown, G. T., \& Teo, T. (2017). Toward an understanding of preservice English as a Foreign Language teachers' acceptance of Computer-Assisted Language Learning 2.0 in the People's Republic of China. Journal of Educational Computing Research, 56(1), 74-104. https://doi.org/10.1177/0735633117700144

Mirici, H., Hoşgörür, V., Arslan, M. M., \& Aydın, A. (2000). Anadolu liselerinde yabancı dille yapılan öğretim ile ilgili öğretmen, öğrenci, veli ve denetçilerin görüşleri [Opinions of teachers, students, parents and inspectors on education in foreign language at Anatolian High Schools]. Education and Science, 25(118), 18-25. Retrieved from http://egitimvebilim.ted.org.tr/index.php/EB/article/view/5297/1458

Muganga, L., \& Ssenkusu, P. (2019). Teacher-Centered vs. Student-Centered: An examination of student teachers' perceptions about pedagogical practices at Uganda's Makerere University. Cultural and Pedagogical Inquiry, 11(2), 16-40. https://doi.org/ 10.18733/cpi29481

O’Dowd, R. (2018). Innovations and challenges in using online communication technologies in CLIL. Theory into Practice, 57(3), 232-240. https://doi.org/10.1080/00405841.2018.1484039

OECD. (2015). Education policy outlook 2015: Making reforms happen. Paris: OECD Publishing. Retrieved from https://www.oecd-ilibrary.org/education/education-policy-outlook-2015_9789264225442-en

Pladevall-Ballester, E. (2015). Exploring primary school CLIL perceptions in Catalonia: Students', teachers' and parents' opinions and expectations. International Journal of Bilingual Education and Bilingualism, 18(1), 45-59.

Rahimi, M., \& Yadollahi, S. (2011). ICT use in EFL classes: A focus on EFL teachers' characteristics. World Journal of English Language, 1(2), 17. http://dx.doi.org/10.5430/wjel.v1n2p17

Republic of Turkey Ministry of Education. (2016). Teacher competencies: Teaching profession general and special field. Retrieved from: https://oygm.meb.gov.tr/

Roiha, A. S. (2014). Teachers' views on differentiation in Content and Language Integrated Learning (CLIL): Perceptions, practices and challenges. Language and Education, 28(1), 1-18. https://doi.org/10.1080/09500782.2012.748061

Scherer, R., Siddiq, F., \& Tondeur, J. (2019). The Technology Acceptance Model (TAM): A meta-analytic structural equation modeling approach to explaining teachers' adoption of digital technology in education. Computers \& Education, 128, 13-35. https://doi.org/10.1016/j.compedu.2018.09.009

Siddiq, F., Scherer, R., \& Tondeur, J. (2016). Teachers' emphasis on developing students' digital information and communication skills (TEDDICS): A new construct in 21 st century education. Computers \& Education, 92-93, 1-14. https://doi.org/10.1016/j.compedu.2015.10.006

Smajla, T. (2021). The Suitability of Foreign Language Teaching in Childhood According to the CLIL Approach: The Foreign Language Teachers' Attitudes. English Language Teaching Educational Journal, 4(1), 1-14. https://doi.org/10.12928/eltej.v4i1.3702

Strauss, A., \& Corbin, J. (2015). Basics of qualitative research: Grounded theory procedures and techniques. Newbury Park, CA: Sage.

Tanış, A., \& Dikilitaş, K. (2019). Exploring CLIL in Turkish context: Teacher and student voices. AJAL, 144165. Retrieved from https://faapi.org.ar/wp-content/uploads/2021/02/Ajal_Vol72.pdf\#page=144

Teo, T., Huang, F., \& Hoi, C. K. W. (2018). Explicating the influences that explain intention to use technology among English teachers in China. Interactive Learning Environments, 26(4), 460-475. https://doi.org/10.1080/10494820.2017.1341940

Teo, T. (2011). Factors influencing teachers' intention to use technology: Model development and test. Computers \& Education, 57(4), 2432-2440. https://doi.org/10.1016/j.compedu.2011.06.008 
Tondeur, J., Van Braak, J., Ertmer, P. A., \& Ottenbreit-Leftwich, A. (2017). Understanding the relationship between teachers' pedagogical beliefs and technology use in education: A systematic review of qualitative evidence. Educational Technology Research and Development,65(3), 555-575. https://doi.org/10.1007/s11423-016-9481-2

Wu, J., \& Du, H. (2012). Toward a better understanding of behavioral intention and system usage constructs. European Journal of Information Systems, 21(6), 680-698. https://doi.org/10.1057/ejis.2012.15

Zhao, K., \& Lei, C. (2019). Technology-enhanced content and language integrated learning in Chinese tertiary English classes: Potentials and challenges. In H. Reinders, C. Coombe, A. Littlejohn, \& D. Tafazoli (Eds.). Innovation in language learning and teaching: The case of the Middle East and North Africa, (pp. 89-113). London: Palgrave Macmillan. 